\title{
The Peculiarities of the Semantic Structure of Lexemes Bärnk and Anchn (Based on the Kalmyk Heroic Epic "Dzhangar")
}

\author{
Evgenii V. Bembeev', Grigorii Ts. Piurbeev', \\ Vladimir N. Mushaev', Liudmila A. Lidzhieva ${ }^{\text {c* }}$ \\ ${ }^{a}$ Kalmyk Scientific Center of the RAS \\ 8 I.K. Ilishkin Str., Elista, 358000, Russia \\ ${ }^{b}$ Institute of Linguistics of the RAS \\ 1/1 per. B. Kislovskii, Moscow, 125009, Russia \\ ${ }^{c}$ Kalmyk State University named after B.B. Gorodovikov \\ 11 Pushkin Str., Elista, 358000, Russia
}

Received 05.12.2018, received in revised form 28.12.2018, accepted 10.01.2019

The analysis of the semantic structure of the word, the identification or restoration of its meaning in the epic work is a difficult task, which is due to the chronological heterogeneity of different versions of the epic, the loss or ambiguity of the semantics of the word, its transition from active to passive vocabulary, or a change of its form. The solution of such a task requires a rigorous analysis of lexical units, taking into account the nature of the contextual environment and the co-occurrence of words, the peculiarities of their semantic definition in lexicographical sources, grammatical and accentological features of the units under consideration.

The article provides the analysis of the semantic structure of lexemes bäryk and anchn, used in the heroic epic "Dzhangar". The analysis allows to identify and restore the meaning of a particular lexeme, which is interpreted differently or is considered to belong to nonequivalent vocabulary. The meaning 'dagger' of the lexeme bäryk is indirectly confirmed by its use in the context of the epic (version of Dava Shavaliev). The lexeme anchn, used as epithets, may denote two different concepts. When used with the word zürkn 'heart', it means 'state of excitement', 'agitated', 'beating quickly'. When used with the word bäryk 'dagger', it can be interpreted as 'huge, big'.

Keywords: Kalmyk language, epic "Dzhangar", explanatory dictionary, semantics, context, lexeme, text corpus.

(C) Siberian Federal University. All rights reserved

* Corresponding author E-mail address: galdma@yandex.ru; pyurbeev@yandex.ru; mushaev_vn@mail.ru; lidzhieva-la@mail.ru This work is licensed under a Creative Commons Attribution-NonCommercial 4.0 International License (CC BY-NC 4.0) 
The study was conducted within the framework of state subsidies - the project "Explanatory Dictionary of the Kalmyk heroic epic "Dzhangar"(state registration number 114071170020) and a grant from Kalmyk State University named after B.B. Gorodovikov "Typology and dynamics of language processes in the Turkic-Mongolian area”.

Research area: philology.

Citation: Bembeev, E.V., Piurbeev, G.Ts., Mushaev, V.N., Lidzhieva, L.A. (2019). The peculiarities of the semantic structure of lexemes bärnk and anchn (based on the Kalmyk heroic epic "Dzhangar"). J. Sib. Fed. Univ. Humanit. soc. sci., 12(1), 32-46. DOI: 10.17516/19971370-0378.

\section{Introduction}

When compiling explanatory dictionaries, one of the main tasks is correct semantization, or disclosure of the meaning of words, their clear, precise and comprehensible definition. In the course of creating the Explanatory Dictionary of the language of the Kalmyk heroic epic "Dzhangar", the authors came across lexemes, the meanings of which are unclear or mistranslated into Russian. Meanwhile, the correct understanding of the epic text and its practical mastery is largely determined by the knowledge of the peculiar features of its vocabulary. As E.Ch. Bardaev rightly noted, "for modern native speakers of the Kalmyk language, the semantics of a large number of archaic words became incomprehensible, or even completely lost. In this connection, linguists face the problem of restoring the history of these words, finding their meaning or, at least, the meaning closest to it" (Bardaev, 1978: 393). Numerous examples of the archaic vocabulary of the Oirat (Kalmyk) language are found in the works of folklore and first of all in the heroic epic "Dzhangar". The epic holds a special place in the culture of the Kalmyks, being a treasury of traditions which reflect the ancient self-consciousness and mental outlook of the nomadic people. It represents the epic ideal worldview and linguistic worldview in the main categories, universals and specific features, characteristic of the traditional worldview of an ethnos. For centuries transmitted by word of mouth of the rhapsodists-storytellers (Dzhangarchi), undergoing various transformations, stratifications and revisions, the epic "Dzhangar" went through a difficult path of development from the epic archaic to the classic heroic epic (Kichikov, 1997).

The purpose of this work is to establish or restore the meaning of the lexical unit of bärykl, based on the criteria of the co-occurrence of the word, its grammatical and

1 The correspondence of Kalmyk orthographic signs to the characters adopted in this article: $ə-\ddot{a}, \theta-\ddot{o}, Y-\ddot{u}$, $\mathrm{h}-\mathrm{\gamma}, \mathrm{H}-\mathrm{y}$, ж-d $\mathrm{d}$. 
accentological features. In this regard, it is necessary to mention a number of works devoted to the etymologization of the lexico-semantic (thematic) group of weapon names in Mongolian languages. Undoubtedly, one of the most significant achievements in this direction is the work of A.V. Dybo, where extensive factual material was consistently used to reconstruct the names of weapons for the Pre-Altaic, Pre-Mongolian, PreNorth Mongolian and Oirat languages (Dybo, 2015). The article by G.Ts. Piurbeev (Piurbeev, 2011) is devoted to the analysis of military terminology on the material of Mongolian-Oirat legal records of the $17^{\text {th }}-18^{\text {th }}$ centuries. The reconstruction of the meanings of some lexical units of the epic "Dzhangar" is presented in several works by V.V. Kukanova (Kukanova, 2016a; 2016b).

\section{Material and research methods}

The research material consists of 28 texts of the recordings of the Kalmyk heroic epic "Dzhangar", which are either combined into repertory cycles of songs or represented by separate songs. According to the research tradition and the chronological principle (Kichikov, 1997: 168), the following stages of the written fixation of the texts of the epic are revealed:

I. Early recordings: Maloderbetovskii cycle (3 songs recorded in 1862), Bagatsokhurovskii cycle (3 songs recorded in 1854-1862).

II. Records of the first half of the $20^{\text {th }}$ century: the epic cycle of the narrator Eelian Ovla (10 songs and magtal-glorification recorded in 1908-1909), the epic cycle of the narrator Mukebiun Basangov (6 songs recorded in 1939), the epic cycle of the narrator Dava Shavaliev (4 songs and magtal recorded in 1939), 1 song from the repertoire of Badma Obushinov (recorded in 1901).

III. Later recordings: 1 song from the repertoire of Nasanka Baldyrov (recorded in 1966).

The automatic analysis of the text corpus of the epic "Dzhangar" was carried out with the help of the morphological analyzer "TextAnalyzer", which makes the identification different language units in a written text much easier, provides information about their frequency, their distribution in texts of different genre, co-occurrence with other units, etc. (Bembeev, Kukanova, Kadzhiev, 2014). This method makes it possible to use a great deal of information, which in turn gives grounds to choose the analysis of lexical units in their contextual links as one of the main ones for the purposes of the

The Kalmyk Folklore Collection, which includes representative songs of the epic "Dzhangar" and their translations, is being created at the Kalmyk Scientific Center of the Russian Academy of Sciences. 
research. The method lies in the fact that typical co-occurrence of every word can be determined by generalizing from a broad illustrative material. This co-occurrence can be represented as a generalized characteristic of the positions most often realized in the context surrounding the lexical unit.

The lexical meaning of a word is a multidimensional phenomenon, consisting of a number of diverse components. To determine the meaning of the word we either proceed on the basis of the contextual surrounding or rely on semantic definitions given in dictionaries. The following lexicographical sources were used to reveal and reconstruct the meanings of lexical units: "Mongolian-Russian-French dictionary" (Kovalevskii, 1844-1849), "Mongolian-Russian dictionary" (Golstunskii, 18931895), "Kalmyk-Russian dictionary" (Pozdneev, 1911), "Kalmyk-German dictionary" (Ramstedt, 1935), "Experience of linguistic study of the epic "Dzhangar" (Todaeva, 1976), "Kalmyk-Russian Dictionary" (ed. by Muniev, 1977), "Dictionary of the Oirats of Xinjiang" (Todaeva, 2001), "Explanatory Dictionary of the Traditional Life of the Oirats of Mongolia and the Kalmyks" (Tsendee, Piurbeev, 2016), "The Big Academic Mongolian-Russian Dictionary" (ed. by Luvsandendev, Tsedendamba, Piurbeev, 20012002), "Oirat-Mongolian Dictionary" (Galzan, 2006).

\section{Determining the meaning of lexical units}

\section{Lexeme bäryk (10)}

The lexical unit bäryk is found only in the repertoire of Dava Shavaliev (Table 1). Considering the context in which this lexeme is used, we come to the conclusion that it means cold steel arms and is accompanied by the following epithets: Anchn nertä dogshn khar bäryk, Kiitn khar bäryk, Achn nertä kiitn khar bäryk, Anch nertä bäryk, dogshn khar bäryk etc. Authors of translations and compilers of "The Kalmyk Folklore Collection" ${ }^{2}$ in some cases (5 out of 10) include this lexeme in the group of non-equivalent vocabulary.

As can be seen from the above examples, in some cases the lexeme bärgk is translated as 'weapon' in combination with the non-translatable element 'biarinke, biarenke' ( 3 times). In some episodes, the word bärgk is interpreted by the authors of the translation of the text as 'spear' or 'sword'. However, it should be noted that in the Kalmyk language there are words referring to these types of cold arms: dzid 'pike, spear, bayonet', arm 'javeline, dart', üld 'sword'. Having considered the context of the

The brackets indicate the number of occurrences of the word in the text.

In these examples, translations are provided according to the texts of the Kalmyk Folklore Collection. 
Table 1. Use of the lexeme bäryk in the texts of the epic "Dzhangar"

\begin{tabular}{|c|c|c|}
\hline & 1 & 2 \\
\hline 1 & $\begin{array}{l}\text { Ölzäyän xal'dayad iovdg } \\
\text { Anchn nertä dogshn khar bärnkig } \\
\text { Suylad avkhin chingäd, } \\
\text { Örgä dotr yal padrad bääv. } \\
\text { [ShD: IV] }\end{array}$ & $\begin{array}{l}\text { Prinosiashchii pol'zu } \\
\text { Svirepyi chernyi biarinke } \\
\text { S nazvaniem Anchin } \\
\text { Edva uspel vytashchit' [iz nozhen], } \\
\text { Vo dvore polykhnulo svetom-ognem } \\
\text { (Advantageous } \\
\text { Fierce black biarinke } \\
\text { Named Anchin } \\
\text { [He] hardly pulled out [of scabbard], } \\
\text { [It] shone brightly and fitfully in the palace) }\end{array}$ \\
\hline 2 & $\begin{array}{l}\text { Achn nertä kiitn khar bärykig } \\
\text { Zövläd, orad irv. } \\
\text { [ShD: III] }\end{array}$ & $\begin{array}{l}\text { Kholodnoe chernoe [oruzhie] biarinke } \\
\text { Napraviv [na nego], priblizilsia. } \\
\text { (Cold black [weapon] biarinke } \\
\text { Having pointed [at him], approached) }\end{array}$ \\
\hline 3 & $\begin{array}{l}\text { Anchn nertä } \\
\text { Dogshn khar bärykin irig } \\
\text { Shuvtn' yurv dolayad orkv. } \\
\text { [ShD: IV] }\end{array}$ & $\begin{array}{l}\text { Lezvie groznogo chernogo mechia svoego, } \\
\text { Imia kotoromu - Anchin, } \\
\text { Trizhdy liznul vo vsiu dlinu [lezviia]. } \\
\text { (The blade of his awe-inspiring black sword } \\
\text { Named Anchin } \\
\text { [He] licked the full length [of the blade] thrice) }\end{array}$ \\
\hline 4 & $\begin{array}{l}\text { Kiitn khar bärykin } \\
\text { Üzür deer kiisäd, } \\
\text { Üksn bäädg chign. } \\
\text { [ShD: I] }\end{array}$ & $\begin{array}{l}\text { Upal na ostrie } \\
\text { Kholodno-chernogo kop'ia } \\
\text { I umer. } \\
\text { ([He] fell on the point } \\
\text { Of the cold black spear } \\
\text { And died) }\end{array}$ \\
\hline 5 & $\begin{array}{l}\text { Anchn nertä } \\
\text { Dogshn khar bärykin irig } \\
\text { Vurv shuvtrad, dolayad orkv } \\
\text { [ShD: IV] }\end{array}$ & $\begin{array}{l}\text { Anchin nazyvaemogo, } \\
\text { Po lezviiu groznogo chernogo mecha } \\
\text { Trizhdy skol'znul iazykom. } \\
\text { (Named Anchin } \\
\text { The blade of the awe-inspiring black sword } \\
\text { [His] tongue licked three times) }\end{array}$ \\
\hline 6 & $\begin{array}{l}\text { «...Ölzän' khaldad iovdg } \\
\text { Anchn nertä bärnkin } \\
\text { Üzür kharyulkhmn», gidłs } \\
\text { Azg Ulan Khoyðr keldzädg bolna. } \\
\text { [ShD:D3M] }\end{array}$ & $\begin{array}{l}\text { «...-Kosnemsia ego ostriem } \\
\text { Oruzhiia, zovushchegosia Anchin } \\
\text { I prinosiashchego schast'e»,-- } \\
\text { Govorit Azyk Ulan Khongor. } \\
\text { (“...Let's touch him with the point } \\
\text { Of the weapon called Anchin } \\
\text { And bringing happiness”, - } \\
\text { Says Azyg Ulan Khongor) }\end{array}$ \\
\hline & $\begin{array}{l}\text { Anchn nertä } \\
\text { Dogshn khar bärykän züüyäd, } \\
\text { Mukhr khar üldän khavchulad, } \\
\text { Mordv. } \\
\text { [ShD: I] }\end{array}$ & $\begin{array}{l}\text { Privesil [k bedru] } \\
\text { Ostroe oruzhie biarinke, } \\
\text { Zasunul za poias korotkii chernyi mech, } \\
\text { Otpravilsia on. } \\
\text { ([He] Hung [on the hip] } \\
\text { Sharp weapon biarinke, } \\
\text { Stuck his short black sword in belt, } \\
\text { He departed) }\end{array}$ \\
\hline
\end{tabular}


Table 1 (Continie)

\begin{tabular}{|c|c|}
\hline $\begin{array}{l}\text { Khärü dävräd, Achn nertä } \\
\text { Kiitn khar bärykär } \\
\text { Örchin kök makhar } \\
\text { Vurv shaayad, yarad odv. } \\
\text { [ShD: III] }\end{array}$ & $\begin{array}{l}\text { Vnov' nastupaia, kholodno-chernym } \\
\text { [Oruzhiem] biarinke, zovushchimsia Achin, } \\
\text { Po sinim myshtsam grudi } \\
\text { Trizhdy kol'nul ego. } \\
\text { (Attacking again, with cold black } \\
\text { [steel] biarinke called Anchin, } \\
\text { The blue chest muscles } \\
\text { [He] stung three times) }\end{array}$ \\
\hline $\begin{array}{l}\text { Anch nertä } \\
\text { Bärnkin ishärn' } \\
\text { Kiitn khar yazr shaayad, } \\
\text { Üzür deern' kiisäd, ükv. } \\
\text { [ShD: I] }\end{array}$ & $\begin{array}{l}\text { Drevko kop'ia } \\
\text { Po nazvaniiu Anchi } \\
\text { Votknul v kholodnuiu chernuiu zemlu, } \\
\text { [Zatem] upal on na ostrie kop'ia i umer. } \\
\text { (The pikesaff } \\
\text { Called Anchi } \\
\text { [He] stuck into the cold black earth, } \\
\text { [Then] fell on the point of the spear and died) }\end{array}$ \\
\hline $\begin{array}{l}\text { Dogshn khar bärykig } \\
\text { Öräldäd suylad avkhin düngäd... } \\
\text { [ShD: DzM] }\end{array}$ & $\begin{array}{l}\text { Svirepyi chernyi biarinke } \\
\text { Kogda [Khongor] napolovinu iz nozhen } \\
\text { vynul... } \\
\text { (Fierce black biarenki } \\
\text { When [Khongor] half unsheathed...) }\end{array}$ \\
\hline
\end{tabular}

usage of this lexeme, it can be noted that the object that it refers to has a 'tip, point' üzür, a 'blade' ir, a 'hilt' ish, i.e. is some kind of pointed or bladed weapon. Moreover, in the given contexts, the word form bäryk is accompanied by the epithets 'black' khar, 'fierce' dogshn, 'cold' kiitn, which metaphorically express the basic qualities of cold weapons, including the quality of strength. It should be noted that the word is found and used only in the epic text of Dava Shavaliev's repertoire (anyway, it was not found in a NCKL).

This lexeme is not found in the above lexicographic sources, apart from the only source of the "Oirat-Mongolian dictionary" of the Oirats of Xinjiang of the People's Republic of China, where [barinki] is interpreted as akhr üld 'short sword' (Galzan, 2006: 429).

In the monograph by G.Ts. Piurbeev "Epic "Dzhangar": Culture and Language" bäryk is translated as 'a straight blade, a pointed sword' (Piurbeev, 2015: 59). According to A.V. Dybo, this lexeme goes back to 'Middle Ossetic Digor burunk', iron. birink' $\propto-$ 'snout, beak, cog, tip', kardy burunk' 'point of a knife' (Abaev, 1958: 283). The Ossetic word probably represents the contamination of Iranian *prnk, Sogdian prynk' 'part of the face', Persian foronğ 'oral region' Farhangnevīs 3, 1897 (cf. Rastorgueva, Edel'man, 2007: 56), and Turkic *burun 'nose' (Dybo, 2015: 241). 
We assume that the word bärgk means 'a dagger' or 'a short sword'. It is known that daggers of Mongolian peoples "are similar in design to swords, are made single and double, but are much shorter than swords. They have narrow long double-edged blades with a stiffening rib running along the entire middle section" (Popenko, 2005: 116). The division of a double-edged hacking-thrusting weapon into short swords and daggers is rather arbitrary, most often "by a short sword is meant a sword up to 60 cm long" (Popenko, 2005: 200). Acknowledged experts in the field of Central Asian weapons L.A. Bobrov and Iu.S. Khudiakov explain: "Short-bladed weapons (daggers and knives) in the late Middle Ages and Modern Times became widespread among the nomads of Central Asia and became an important element of nomads' everyday and festive costume" (Bobrov, Xudiakov, 2008: 292).

In our opinion, the word bärnk correlates with the noun bärm 'measure of length equal to the distance between the extreme points of the fingers clenched into a fist, the thumb rests on the index finger' + affix $-k$, and means 'a small cold weapon held by the fingers clenched into a fist' or 'something that is clenched in a fist'. It is known that in the Kalmyk language relative adjectives are formed with the help of the affix $-k$ : "1) from nouns in the form of the Dative-Locative case: nuryndk (spinal) from nurynd (on the back), gertk (related to home) from the gert (in the house, at home)..; 2) from adverbs of time, place: mayydurk (related to tomorrow) versus mayydur (tomorrow), ardk (rear) from ard (behind)...” (Kalmyk Grammar. Phonetics and morphology, 1983: 137-138). In the colloquial Kalmyk language, the word köldk is used to refer to the shoes in an allegorical manner, literally "what is on the feet". It consists of a noun in the DativeLocative case $k o ̈ l d+$ affix $-k$ [AFM]. Here the process of occasional substantivization, i.e. conversion of an adjective into a noun in a certain context, is observed.

The database of the National Corpus of the Kalmyk language contains, for example, the word küzünk 'collar': Deesn küzünk tuylyn küzünd shigdäd övdkäyäd bääkh giyäd tuyld närkhn khoslngar küzünk kedg bilä (NCKL). - "As far as rope collar would hurt the neck of a calf, collars for calves were made of thin [leather] band". This lexeme is derived from the noun küzün + affix $-k$. As is well known, in the Kalmyk language, the phoneme [n] at the end of the stem before the postdorsal $[\mathrm{k}]$ "interchanges with the corresponding features of the postdorsal nasal phoneme $[\mathrm{g}]$ " (Kalmyk Grammar. Phonetics and morphology, 1983: 38). It should be noted that the form küzünk 'collar' is of little use, reflecting the dialect features, as in this case in the work of K. E. Erendzhenov (NCKL). In the literary Kalmyk language, the established form is considered to be küzüvch 'collar' (Kalmyk-Russian Dictionary, 1977: 323). 
There are a number of proper names, as well as names of plants, formed by adding

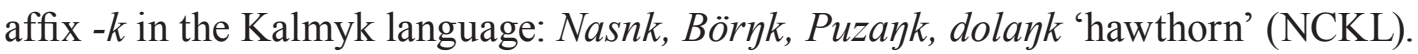

As for the interchange of [n] into [m], depending on the dialectal features, there are cases of such phonetic changes, for example: nand 'to me' - namd; nanla 'with me' namla (Kalmyk Grammar. Phonetics and morphology, 1983: 162). In this regard, you can also give an example of the lexeme ünr 'smell' - > [üykä] - > ümkä [dial. ömkä] ‘stinking, rotten, malodorous' (Kalmyk-Russian Dictionary, 1977: 551-552; AFM).

The meaning of the word bärnk as a 'dagger' is indirectly confirmed by the way this object is used by the heroes of the epic. For example, Khongor bogatyr, who had this type of cold weapon in his arsenal, during the oath-taking ritual, licked its blade three times: Anchn nertä Dogshn khar bärykin irig yurv shuvtrad, dolayad orkv. [ShD: IV] - 'He licked the blade of the awe-inspiring black sword called Anchn three times'. A similar ritual among the Mongolian-speaking peoples is recorded in many historical documents. For example, the description of the oath of allegiance (shert') sworn by Kalmyk rulers to the contractual relationship with the Russian state: "In Moscow the ambassador was asked about the ritual of oath taking practiced by the Kalmyks. He replied: They lick the knife and put an arrow on the head and put it to the heart, they consider it to be an oath, and their present Baibagas-taisha to his oath to the czar in the same way" (Mitirov, 1998: 183).

Thus, we assume that the word bärnk means 'dagger' - a type of hacking-thrusting weapon with a long, narrow, double-edged blade up to $40 \mathrm{~cm}$ long.

\section{Lexeme Anchn}

It can be seen from the context that the word form bärnk is accompanied by adjectival epithets khar 'black', dogshn 'fierce', kiitn 'cold', which in this context reinforces the basic quality of the dagger, including the notion of strength. In addition, this steel weapon has its own name-Anchn, in two cases it is referred to as Achn, Anch. Interestingly, the name of Anchn is given to 'dagger' and to 'heart'as well. As an epithet to 'heart', this lexeme is found not only in the songs from the repertoire of Dava Shavaliev, but also in cycles of songs by Eelian Ovla and Mukuben Basangov. It is revealed that in the texts of the epic "Dzhangar" this lexeme is used 20 times as an epithet to the word zürkn 'heart', and 6 times as an epithet to the word bärnk 'dagger' (only in the songs by D. Shavaliev) (Table 2-3).

In his dictionary a famous Altaist G.J. Ramstedt defines lexeme antṣ̌! (anchn) as 'stellung, richtung, das richtige verständnis' ('position, direction, correct understanding'). He also notes here that anchn is a synonym for $\ddot{a} w r$ and gives the 
Table 2. Use of the lexeme Anchn (26) in "Dzhangar"

\begin{tabular}{|c|c|c|}
\hline 1. & $\begin{array}{l}\text { / Bumbin tsayan cheedzn’ / Budn ik } \\
\text { kharyyu bolv, / Anchn gidg zürkn’ } \\
\text { / Äävlkhäyin' güvdv. [BTs: III] }\end{array}$ & $\begin{array}{l}\text { Belaia bumbaiskaia grud' stala temnoi, slovno v tumane, } \\
\text { serdtse, zovushcheesia Anchn, uchashchenno zabilos'. } \\
\text { (White chest of Bumba / turned dark as if in the fog, /the } \\
\text { heart called Anchn / pounded quickly) }\end{array}$ \\
\hline 2. & $\begin{array}{l}\text { / Anchn gigch zürkn' / } \\
\text { Äävlkhäyin' güvdäd, / Arvn khoir } \\
\text { sürän’ / Amn ööd devräd, / Arvn } \\
\text { tsayan khuryn' / Al'khn taln' } \\
\text { üümldäd irv. [EO: III] }\end{array}$ & $\begin{array}{l}\text { Serdtse, zovushcheesia Anchn, uchashchenno zabilos' [v } \\
\text { grudi], dvenadtsat' otvag stali vyryvat'sia iz-za rta, desiat' } \\
\text { belykh pal'tsev sydorozhno szhimalis' k ladoniam. } \\
\text { (The heart called Anchn started beating quickly [in the } \\
\text { chest], twelve valours started coming out of the mouth, ten } \\
\text { white fingers twitched) }\end{array}$ \\
\hline 3. & $\begin{array}{l}\text { / Anchn nertä zürkn / Äävlkhä } \\
\text { dotrn' doldalgsn, / Arvn tsayan } \\
\text { khuryn' / Al'khn dotrn' üümldäd } \\
\text { bosv. [ShD: II] }\end{array}$ & $\begin{array}{l}\text { Serdtse, zovushcheesia Anchn, uchashchenno zabilos' v } \\
\text { grudi, desiat' belykh pal'tsev sydorozhno szhimalis' k } \\
\text { ladoniam. } \\
\text { (The heart called Anchn started beating quickly [in the } \\
\text { chest], twelve valours started coming out of the mouth, ten } \\
\text { white fingers twitched) }\end{array}$ \\
\hline 4. & $\begin{array}{l}\text { Anch nertä / Bärnkin ishärn’/ Kiitn } \\
\text { khar yazr shaayad, / Üzür deern’ } \\
\text { kiisäd, ükv. [ShD: I] }\end{array}$ & $\begin{array}{l}\text { Rukoiatku kinzhala biarinke, } \\
\text { Po nazvaniiu Anchi, } \\
\text { Votknul v kholodnuiu chernuiu zemliu, } \\
\text { [Zatem] upal on na ostrie i umer. } \\
\text { (The hilt of the dagger biarinke } \\
\text { called Anchi stuck into the cold black earth [then] fell onto } \\
\text { the blade and died) }\end{array}$ \\
\hline 5 & $\begin{array}{l}\text { Anchn nertä / Dogshn khar bärnkän } \\
\text { züüyäd, / Mukhr khar üldän } \\
\text { khavchulad, mordv. } \\
\text { [ShD: I] }\end{array}$ & $\begin{array}{l}\text { Privesil [k bedru] } \\
\text { Ostryi chernyi kinzhal biarinke, po nazvaniiu Anchn, } \\
\text { Zasunul za poias korotkii chernyi mech, } \\
\text { Otpravilsia on. } \\
\text { ([He] Hung [on the hip] } \\
\text { Sharp weapon biarinke called Anchin } \\
\text { Stuck his short black sword in belt, } \\
\text { He departed) }\end{array}$ \\
\hline
\end{tabular}

following examples as an illustration: antšnn amně-w 'ich will das unrersuchen, ich will mich darin orientieren' ('I want to investigate it, I want to orientate in it') (Ramstedt, 1935: 11). From the point of view of etymology, G.J. Ramstedt assumes that it goes back

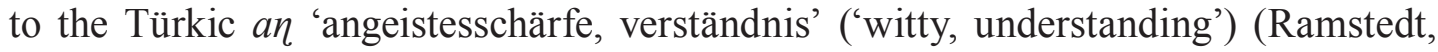
1935: 11). The verb antšl $x^{p}$ (anchlkh) 'untersuchen, durchforschen kritisch nachsehen, sich orientieren' ('investigate, look critically, orientate') is also found in G. Ramstedt's dictionary (Ramstedt, 1935: 11).

The researcher of the epic "Dzhangar" B.Kh. Todaeva translates the lexeme anchn as 'tested', 'proven', 'huge' and believes that it is formed by adding a wordformation suffix of adjectives $-n$ to the stem of the noun anch, 'orientation', 'correct understanding' (Todaeva, 1976: 125). According to the author, the lexeme anchn, 
Table 3. Lexeme anchn and similar words in lexicographical sources

\begin{tabular}{|c|c|c|c|c|c|c|c|}
\hline Lexeme & $\begin{array}{c}\text { Pozdneev } \\
1911\end{array}$ & $\begin{array}{c}\text { Ramstedt } \\
1935\end{array}$ & $\begin{array}{c}\text { Todaeva } \\
1976\end{array}$ & KRD 1977 & $\begin{array}{c}\text { Todaeva } \\
2001\end{array}$ & D. Galzan 2006 & BAMRD \\
\hline $\begin{array}{l}\text { anchn } \\
\text { [ančin] }\end{array}$ & - & - & $\begin{array}{l}\text { fig. 'big, } \\
\text { huge' } \\
{[1976:} \\
188]\end{array}$ & $\begin{array}{l}\text { 'excited, } \\
\text { racing (of } \\
\text { heart)' } \\
\text { [1977: 44] }\end{array}$ & - & $\begin{array}{l}\text { I. [ančin] 'big, huge'; } \\
\text { II. 1) [ančin] } \\
\text { 'description of a } \\
\text { heart racing; } \\
\text { 2) description of } \\
\text { bravery [2006: 8] }\end{array}$ & - \\
\hline $\begin{array}{l}\text { anch } \\
\text { [anči] }\end{array}$ & - & $\begin{array}{l}\text { antš! 'stellung, } \\
\text { richtung, } \\
\text { das richtige } \\
\text { verständnis } \\
\text { (?)' ('position, } \\
\text { direction, } \\
\text { correct } \\
\text { understanding) } \\
\text { [1935: 11] }\end{array}$ & - & $\begin{array}{l}\text { [anch- } \\
\text { bäädl] } \\
\text { situation } \\
\text { [1977: 44] }\end{array}$ & - & $\begin{array}{l}\text { [anči] } \\
\text { 1)'appearnce', } \\
\text { 2) 'situation, } \\
\text { position'; } \\
\text { 3) 'name of a plant' } \\
\text { [2006: 8] }\end{array}$ & - \\
\hline $\begin{array}{l}\text { aychn } \\
\text { [ayčin] }\end{array}$ & - & $\begin{array}{l}\text { antš! 'jäger' } \\
\text { ('hunter') [1935: } \\
\text { 12] }\end{array}$ & - & & $\begin{array}{l}\text { aychn } \\
\text { 'hunter' }\end{array}$ & - & $\begin{array}{l}\text { anch(in) } \\
\text { 'hunter, } \\
\text { trapper, } \\
\text { catcher' } \\
\text { [2001: 101] }\end{array}$ \\
\hline
\end{tabular}

being a synonym for the word $\ddot{a} v r$ I. '1) behaviour, temper, character', '2) caprice \| capricious; II. "big", “enormous”, "titanic” (Kalmyk-Russian Dictionary, 1977: 64), due to the wide use of the latter, was ousted from the active lexical fund of the modern Kalmyk language. "One can assume," writes B.Kh. Todaeva, "that out of two words with the same semantics, one gradually goes out of use, being replaced by a more stable, widely used ... ... over time, anch and anchl-have fallen out of use, only the text of the songs witnessed anchn" (Todaeva, 1976: 125). The vocabulary of the modern Kalmyk language contains the paired word ävr-anch [ävr-anchî] paired 1) mood;2) behavior (Todaeva, 1976: 64).

In the dictionary of the Oirats of Xinjiang, two meanings of the word anchn are given I. [ančin] 'big, huge'; II. 1) [ančin] 'description of a beating heart'; 2) 'description of courage' (Galzan, 2006: 8). Thus, it can be assumed that in each case the word anchn may be interpreted differently.

\section{Conclusion}

The study of the context, in which the lexemes under considerations are used, and the corresponding material of various lexicographic sources allows not only to identify or restore the meaning of a particular lexeme, but in some cases to 
identify differences in the semantics of the same lexeme. These differences can be explained by the difference of contexts of use, which, in turn, are determined by the stadial features of a particular version of the epic, by specificity of a performing school, as well as by the time the written record of the oral performance of the epic text was made. The analysis of the semantic structure of lexemes bäryk and anchn in the Kalmyk heroic epic "Dzhangar" presented in this paper suggests the following. The lexeme bärgk can mean 'dagger' and correlates with the noun bärm 'measure of length equal to the distance between the extreme points of the fingers clenched into a fist, the thumb rests on the index finger' + affix $-k$ and has the meaning 'a small cold weapon held by fingers clenched into a fist' or 'something that is clenched in the fist'.

The lexeme anchn used as an epithet may denote two different concepts. If it is used with the word zürkn 'heart', then it describes the state of excitement and courage of this or that bogatyr: 'agitated, beating quickly (about the heart)'. The epithet Anchn used with the word bäryk 'dagger', can be interpreted as 'huge, big'.

\section{References}

Abaev, V.I. (1958). Istoriko-etimologicheskii slovar' osetinskogo iazyka [Historical Etymological Dictionary of the Ossetic Language]. Moscow, Leningrad, Nauka, 1, 659.

Bardaev, E.Ch. (1978). Nekotorye voprosy izucheniia leksiki «Dzhangar» [Some questions of "Dzhangar" vocabulary study]. In Materialy Vsesoiuznoi nauchnoi konferentsii "Dzhangar i problemy epicheskogo tvorchestva tiurko-mongol'skikh narodov [Materials of the All-Soviet Union Scientific Conference "Dzhangar" and the problems of the epic tradition of the Turkic-Mongolian peoples]. Elista, 390-396.

Bembeev, E.V., Kukanova, V.V., Kadzhiev, A.Iu. (2014). Chastotnyi slovar' sovremennogo kalmytskogo yazyka: pravila analiza tekstovogo materiala [Frequency dictionary of the modern Kalmyk language: rules of text analysis], In Vestnik Kalmytskogo instituta gumanitarnykh issledovanii RAN [Bulletin of the Kalmyk Institute for Humanitarian Studies of the Russian Academy of Sciences], 3, 128-141.

Bobrov, L.A., Xudiakov, Iu.S. (2008). Vooruzhenie i taktika kochevnikov Central'noi Azii i Yuzhnoi Sibiri v epoxu pozdnego Srednevekov'ya i rannego Novogo vremeni (XV - pervaya polovina XVIII v.). [Armament and tactics of nomads of Central Asia and South Siberia in the epoch of the late Middle Ages and early Modern times (15 th - the first half of the $18^{\text {th }}$ century]. Saint Petersburg, Filologicheskii fakul'tet SPbGU, $774 \mathrm{p}$. 
Bol'shoi akademicheskii mongol'sko-russkii slovar' $\mathrm{v}$ 4-kh tomakh [The Big Academic Mongolian-Russian Dictionary in 4 vols.] (2001-2002). Ed. by A. Luvsandendev, Ts. Tsedendamba, G.Ts. Piurbeev Moscow, Academia, 1-4, 502 p., 536 p., 440 p., 532 p.

Dybo, A.V. (2015). Nazvaniia oruzhiia: ot praaltaiskogo k mongol'skomu [Weapon names: from Pre-Altaic to Mongolian], In Rossiisko-mongol'skii lingvisticheskii sbornik [Russian-Mongolian linguistic collection], 209-254.

Galzan, A. (2006). Öörd-moyyl tol' (Ojrat-mongol'skii slovar') v 4-kh tomakh [Oirat-Mongolian Dictionary in 4 vols.]. Karamai, 1-4, 2011 p.

Golstunskii, K.F. (1893, 1894, 1895). Mongol'sko-russkii slovar' v 3-kh tomakh [Mongolian-Russian dictionary in 3 vols.]. Saint Petersburg: Litografiia imeni A. Ikonnikova, 1-3, 268 p.; 462 p; 491 p.

Grammatika kalmyczkogo yazyka. Fonetika i morfologiya (1983). [Kalmyk Grammar. Phonetics and morphology]. Elista, Kalmytskoe knizhnoe izdatel'stvo, 335 p.

Kalmytsko-russkii slovar' [Kalmyk-Russian Dictionary] (1977). ed. by B.D. Munieva. Moscow, Russkii iazyk, 768 p.

Kichikov, A.Sh. (1997). Geroicheskii epos «Dzhangar». Sravnitel'notipologicheskoe issledovanie pamiatnika [Heroic epic "Dzhangar". A comparative typological study of the monument]. Moscow, Vostochnaia literatura, 320 p.

Kovalevskii, O.M. (1844, 1846, 1849). Mongol'sko-russko-frantsuzskii slovar' v 3-kh tomakh [Mongolian-Russian-French Dictionaryin 3 vols]. Kazan, Universitetskaia tipografiia, 1-3, $2690 \mathrm{p}$.

Kukanova, V.V. (2016a). Opyt rekonstrukcii znachenii leksicheskikh edinits, upotrebliaiushchikhsia $\mathrm{v}$ epose «Dzhangar» [Reconstruction of the meaning of the lexical units used in the epic "Dzhangar"], In Mongolovedenie [Mongolian Studies], 8, 184-198.

Kukanova, V.V. (2016b). Opyt rekonstrukcii znachenii leksicheskikh edinits, upotrebliaiushchixsia v epose «Dzhangar» [Reconstruction of the meaning of the lexical units used in the epic "Dzhangar"], In Vestnik Kalmytskogo instituta gumanitarnykh issledovanii RAN [Bulletin of the Kalmyk Institute of Humanitarian Studies of the Russian Academy of Sciences], 4, 121-131.

Mitirov, A.G. (1998). Oiraty-kalmyki: veka i pokoleniya [Oirats-Kalmyks: centuries and generations]. Elista, Kalmytskoe knizhnoe izdatel'stvo, 384 p.

Natsional'nyj korpus kalmytskogo yazyka (2012). [National Corpus of the Kalmyk language] [Web-site]. URL: http: kalmcorpora.ru. 
Piurbeev, G.Ts. (2011). Voennaia terminologiia na materiale mongolo-ojratskikh pamiatnikakh prava XVII-XVIII vv. [Military terminology based on the materials of the Mongol-Oirat monuments of law of the XVII-XVIII centuries]. In Materialy Mezhdunarodnoi nauchnoi konferentsii "Edinaia Kalmykiia v edinoi Rossii: cherez veka v budushchee" [Materials of the International Scientific Conference "United Kalmykia in United Russia: Through the Centuries into the Future"'], Elista, 2, 283-285.

Piurbeev, G.Ts. (2015). Epos «Dzhangar»: kul'tura i iazyk. [Epic “Dzhangar”: culture and language]. Elista, ZAO "NPP Dzhangar", 280 p.

Popenko, V.N. (2005). Xolodnoe oruzhie. Enciklopedicheskii slovar' [Steel arms. Encyclopedic Dictionary]. Moscow, AST, Astrel, 474 p.

Pozdneev, A.M. (1911). Kalmytsko-russkii slovar'v posobii k izucheniyu russkogo yazyka v kalmytskikh nachal'nykh shkolax. [Kalmyk-Russian dictionary in the textbook on the study of the Russian language in Kalmyk elementary schools]. Saint Petersburg, Tipografiia imperatorskoi Akademii nauk, 312 p.

Ramstedt, G.I. (1935). Kalmükisches Wörterbuch. Helsinki, Suomalais-Ugrilainen Seura, 592 p.

Rastorgueva, V.S., Edel'man, D.I. (2007). Etimologicheskii slovar' iranskikh iazylov [Etymological Dictionary of Iranian Languages]. Moscow, Nauka, 3, $492 \mathrm{p}$.

Todaeva, B.X. (1976). Opyt lingvisticheskogo issledovaniia eposa «Dzhangar» [Linguistic research of the epic “Dzhangar”]. Elista, Kalmytskoe knizhnoe izdatel'stvo, $530 \mathrm{p}$.

Todaeva, B.X. (2001). Slovar' iazyka ojratov Sin'tsziana (Po versiyam pesen «Dzhangara» $i$ polevym zapisiam avtora [The Dictionary of the Xinjiang Oirats (Based on the versions of the songs of the epic "Dzhangar" and the field records of the author]. Elista, Kalmytskoe knizhnoe izdatel'stvo, 494 p.

Tsendee Iu., Piurbeev G.Ts. (2016). Tolkovyi slovar' tradicionnogo byta ojratov Mongolii i kalmykov [Explanatory Dictionary of the Traditional Life of the Oirats of Mongolia and Kalmyks]. Ulaanbaatar, Ganprint, 336 p.

\section{Sources material}

\section{Bagatsokhurovskii cycle}

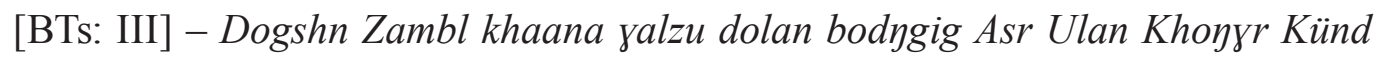
Varta Savr khoir dörätsülgsn bölg. 


\section{Cycle of songs from the repertoire of Eelian Ovla}

[EO: III] - Baatr Khar Dzilyn khaanla bäär bärldgsn bölg.

\section{Cycle of songs from the repertoire of Shavalin Dava}

[ShD: D3M] - Dzayyrin magtal.

[ShD: I] - Arnzlyn khurdn Zeerdig khulkha avsna tusk bölg.

[ShD: II] - Azg Ulan Khoyyrin ger avlyna bölg.

[ShD: III] - Ke shar-tsookhr mörtä Kermin kövün Moฤkhuliala däälldgsn bölg.

[ShD: IV] - Otsl Damban kök yalzn külgtä Azg Ulan Khoךyr nisdg alg mörtä Arl Manz khaag dargsn bölg.

\section{List of reductions}

AFM - Author's field materials.

BAMRD - Bol'shoi akademicheskii mongol'sko-russkii slovar' v 4-kh tomakh. [The Big Academic Mongolian-Russian Dictionary in 4 vols.] (2001-2002). Ed. by A. Luvsandendev, Ts. Tsedendamba, G.Ts. Piurbeev. Moscow, Academia, I-IV, 502 p., 536 p., 440 p., 532 p.

KRD - Kalmytsko-russkii slovar' [Kalmyk-Russian Dictionary] (1977). ed. by B. D. Muniev. Moscow, Russkii iazyk, 768 p.

NCKL - Natsional'nyj korpus kalmytskogo yazyka [National Corpus of the Kalmyk language] (2012). Available at: http: kalmcorpora.ru 


\title{
Особенности семантической структуры лексем \\ бәрцк и анчн (на материале калмыцкого \\ героического эпоса «Джангар»)
}

\author{
Е.В. Бембеев ${ }^{\text {a, }}$ Г.Ц. Пюрбеев ${ }^{\tilde{\sigma}}$, \\ В.Н. Мушаев ${ }^{\text {, }, ~ Л . А . ~ Л и д ж и е в а ~}{ }^{\mathrm{B}}$ \\ ${ }^{a}$ Калмыцкий научный центр РАН \\ Россия, 358000, Элиста, ул. И.К. Илишкина, 8 \\ ${ }^{6}$ Институт языкознания РАН \\ Россия, 125009, Москва, пер. Б. Кисловский, 1, стр. 1 \\ ${ }^{6}$ Калмыцикий государственный университет \\ имени Б.Б. Городовикова \\ Россия, 358000, Элиста, ул. Пушкина, 11
}

\begin{abstract}
Анализ семантической структуры слова, установление или восстановление его значения в эпическом произведении являются сложными задачами, которые обусловлены хронологической неоднородностью разных версий эпоса, утратой или неясностью семантики слова, переходом его из активного бытования в пассивный запас или изменением его формы. Решение подобных задач требует скрупулезного анализа лексических единии, учитывающего характер контекстуального окружения и сочетаемости слов, особенности их семантической дефиниции в лексикографических источниках, грамматические и акиентологические признаки искомых единич.

В статье дается анализ семантической структуры лексем бәрцк и анчн, употребляемых в героическом эпосе "Джангар». Проведенный анализ позволяет установить и восстановить значение отдельной лексемы, которую при переводе авторы трактуют по-разному или же относят ее к безэквивалентной лексике. Значение 'кинжал' для лексемы бәрцк опосредованно подтверждается ее употреблением в контексте эпоса (версия Дава Шавалиева). Лексема анчн, употребляемая в качестве эпитетов, может обозначать два разных понятия. При слове зүркн 'сердие' оно означает 'состояние волнения', 'взволнованный', 'бьющийся учащённо'. Эпитет анчн при слове бәрнук 'кинжал' может трактоваться как 'огромный, большой'.
\end{abstract}

Ключевые слова: калмыцкий язык, эпос «Джангар», толковый словарь, семантика, контекст, лексема, корпус текстов.

Исследование проведено в рамках государственной субсидии - проект «Толковый словарь языка калмыцкого героического эпоса "Джангар» (номер госрегистраиии 114071170020) и гранта КалмГУ «Типология и динамика языковых процессов в тюркомонгольском ареале».

Научная специиальность: 10.00.00 - филологические науки. 